\title{
The gathering and consumption of wild edible plants in the Campoo (Cantabria, Spain)
}

\section{MANUEL PARDO-DE-SANTAYANA ${ }^{1,2}$, JAVIER TARDÍO ${ }^{3}, \&$ RAMÓN MORALES ${ }^{1}$}

\author{
${ }^{1}$ Real Fardín Botánico, CSIC, Madrid, Spain, ${ }^{2}$ Centre for Pharmacognosy and Phytotherapy, \\ The School of Pharmacy, University of London, UK, and ${ }^{3}$ Instituto Madrileño de Investigación \\ Agraria y Alimentaria, Finca El Encín, Madrid, Spain
}

\begin{abstract}
This paper discusses the traditional consumption of wild edible plants in the rural communities of the Campoo (Cantabria), a region in northern Spain. Through semi-structured interviews with key informants, data on the perception, gathering, preparation and use of 60 edible wild plant species were collected. Social, economic and cultural factors need to be taken into account when trying to understand why some wild foods and traditional vegetables continue to be consumed while others are not. Wild foods were traditionally important as a supplement to the diet (particularly during food shortages), to which they bring diversity and serve as a source of vitamins and minerals. However, only a few people who like the taste of wild species and enjoy gathering them continue to consume them. Many people consider wild food to be old fashioned, unprofitable, or too time-consuming, and prefer to cultivate or buy their food. The most frequently cited species in the region (Rumex acetosa, Origanum vulgare, Rosa canina, Vaccinium myrtillus, Crataegus monogyna and Prunus spinosa) are widely consumed in the Mediterranean area. Unusual food species, such as Pedicularis schizocalyx, Romulea bulbocodium or Viburnum lantana, have also been gathered in the study area.
\end{abstract}

Keywords: Wild food, edible plants, ethnobotany, Campoo, Spain

\section{Introduction}

Despite the primary reliance of agricultural societies on crop plants, the tradition of consuming wild plants has not been eliminated. Increasing interest in the wild, edible foods of the Mediterranean region has led to ethnobotanical studies centred on edible plants (Pieroni 1999, 2000; Ertug 2000, 2004; Bonet and Vallès 2002; Pieroni et al. 2002, 2005; Guarrera 2003; Tardío et al. 2005).

In Spain, wild food plants are basically considered as famine food (González Turmo 1997), the consumption of which is linked to times of scarcity. Many dietary and nutritional surveys have ignored the contribution of wild plants. Only a few wild plants, such as Rubus ulmifolius, Rorippa nasturtium-aquaticum, Silene vulgaris, Asparagus acutifolius L. or Scolymus hispanicus L., still have an important role in Spanish food-gathering customs. In Spain, like other European countries, acculturation and globalization have been accompanied by a revaluation of local identities and

Correspondence: Manuel Pardo-de-Santayana, Real Jardín Botánico, CSIC, Plaza de Murillo 2, E-28014 Madrid, Spain. Tel: 34 914203017. Fax: 34 914200159. E-mail: mpardo@ma-rjb.csic.es 
traditions, including traditional cuisines (see Pardo-de-Santayana and Gómez Pellón 2003). This, coupled with the boom in rural tourism and the incentives provided by rural development agencies, has led to an increase in the marketing of locally produced and home-made food products, including jams, infusions and liqueurs.

The aim of this paper is to discuss the wild plants historically gathered in the study area for use as foods, beverages or flavouring agents. These include fruits, vegetables, herbs and plants used in the preparation of liqueurs and infusions drunk daily or after meals. Emphasis was placed on the selection of species, the documenting of food habit changes and the nutritional and healing properties of these plants.

\section{Study area}

The Campoo is located in the south of the Province of Cantabria (northern Spain), which lies on the border between the Mediterranean and Eurosiberian floristic regions (Figure 1). Covering over $1000 \mathrm{~km}^{2}$ and with altitudes exceeding $2000 \mathrm{~m}$ (average $800 \mathrm{~m}$ ), the southern slopes of the Cantabrian Range include a mosaic of meadows, forests, moorlands, rivers and high mountain vegetation growing on varied geological materials and soils. Several types of oak and beech forest dominate the landscape.

The population of the area is around 23,000, half of which lives in the town of Reinosa. Until 1970, the economy of the Campoo was based on agriculture, cattle breeding and a number of minor activities. Each family had a few cows, sheep or goats that were managed collectively, and many households had some pigs and hens. Fields that used to grow cereals (for bread), pulses and potatoes have now given way to pasture for cows. While the household economy was largely subsistence-based, additional income was derived from the sale of animals, eggs, butter and handicrafts. Low salaries meant that even people working in steel, cement and glass factories combined wage labour with cattle raising. The daily diet consisted of bread, pulses, potatoes, cabbage and pork products, complemented with milk, cheese, butter, eggs and honey.

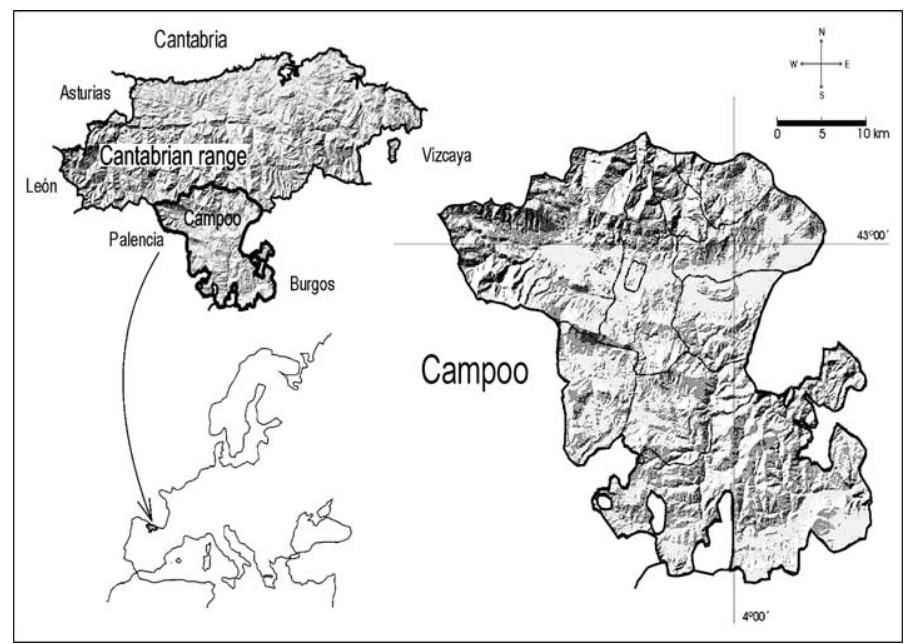

Figure 1. Location of the study area. 


\section{Methods}

The incidence and social context of gathering and consuming wild plants was studied as part of an ethnobotanical survey carried out in the Campoo between 1997 and 2000. Information was obtained through 107 semi-structured interviews of 93 people (age range, 35-90 years; mean age, 68 years). Key informants with a good traditional knowledge of useful wild plants were sought - mostly elderly people who had lived and worked in the region for many years. Open questions were asked about the consumption of wild foods to gain insight into their present-day use, ways of consumption and preparation, the time of collection and the places where each species was gathered.

Although some authors do not consider uses mentioned by only one informant (Johns et al. 1990), we decided to include them as valid statements given the high reliability of the informants and the consistency of their reports (see Alexiades 1996; Scarpa 2000).

The data collected were compared with those of ethnobotanical surveys performed in nearby areas (Blanco 1996; Lastra 2003; San Miguel 2004) and other parts of Spain (e.g. Bonet and Vallès 2002; Tardío et al. 2002) and the Mediterranean (Pieroni 1999, 2000; Ertug 2000), as well as with data in the online database 'Plants for a Future' (PFAF 2005).

\section{Results}

Information was obtained on 60 wild taxa corresponding to 25 botanical families (Pardo de Santayana 2004). Table I summarizes the information of the 40 species whose uses were mentioned by more than two informants. With respect to the diversity of the species gathered, Rosaceae was the most important botanical family; 15 species of this family were at some time collected for their fruits, and seven species of Lamiaceae were used as condiments and in infusions. All the species gathered were autochthonous, except for Mespilus germanica, Sorbus domestica and Prunus cerasus that now grow feral in the area. Mespilus germanica, Prunus avium, Prunus insititia, Sorbus domestica, Ribes uva-crispa and Origanum vulgare are also cultivated in gardens.

The majority of wild species $(42 \%)$ were appreciated for their fruits or seeds, which were gathered at the end of summer or in the autumn. Another important usage group was 'green leaves and young shoots'; the corresponding plants were collected in spring as green vegetables $(25 \%)$. Flowers were sucked for their sweet nectar $(9 \%)$, and flowered aerial plants were used to prepare herbal teas $(9 \%)$ or employed as condiments $(9 \%)$. The underground parts of some species were also consumed (9\%). Some of these species were also used to prepare liqueurs $(34 \%)$.

\section{Mode of preparation and consumption}

Most species were consumed raw and with no kind of preparation, either while walking or working in the field. This group included flowers that were sucked for their sweet taste (e.g. Lamium maculatum), bitter green vegetables (e.g. Oxalis acetosella), other greens (e.g. Tragopogon pratensis), sweet subterranean parts (e.g. Conopodium pyrenaeum) and young shoots (e.g. Rosa canina).

Green vegetables were also eaten raw in salads (e.g. Rumex acetosa, Rorippa nasturtium-aquaticum) or cooked (Silene vulgaris) with pulses or other vegetables. 
Table I. Wild edible plants of the Campoo whose uses are mentioned by more than two informants.

\begin{tabular}{|c|c|c|c|c|c|}
\hline Family/species/voucher number & Local name & $\begin{array}{l}\text { Collecting place } \\
\text { (season) }\end{array}$ & Parts used & $\begin{array}{c}\text { Popular use } \\
\text { (prevalence of use }^{\mathrm{a}} \text { ) }\end{array}$ & $\begin{array}{l}\text { Frequency of } \\
\text { citation }\end{array}$ \\
\hline \multicolumn{6}{|l|}{ APIACEAE } \\
\hline Conopodium pyrenaeum (Loisel.) & Macucos & Meadows (spring) & Tubers & Raw, by children (A) & 9 \\
\hline \multicolumn{6}{|l|}{$\begin{array}{l}\text { Miégev. (779MP) and C. subcarneum } \\
\text { (Boiss. \& Reut.) Boiss. \& Reut. (729MP) }\end{array}$} \\
\hline Scandix australis L. (1562MP) & Anís & Pastures (spring) & Leaves & Raw, by children (A) & 4 \\
\hline \multicolumn{6}{|l|}{ ASTERACEAE } \\
\hline Chamaemelum nobile (L.) All. (223MP) & Manzanilla & Pastures (summer) & Inflorescences & $\begin{array}{l}\text { Liqueur (adding some } \\
\text { flowers to 'pacharán') (C) }\end{array}$ & 4 \\
\hline Taraxacum officinale Weber (232MP) & Diente de león & Meadows (spring) & Leaves & Raw in salads $(\mathrm{C})$ & 5 \\
\hline Tragopogon pratensis L. (833MP) & Lecherín & Meadows (spring) & Tender stems & Raw (A) & 9 \\
\hline \multicolumn{6}{|l|}{ BETULACEAE } \\
\hline Corylus avellana L. (247MP) & Avellana & $\begin{array}{l}\text { Forest, hedges } \\
\text { (autumn) }\end{array}$ & Seeds & $\begin{array}{l}\text { Raw, dried, sometimes } \\
\text { immature (TC) }\end{array}$ & 13 \\
\hline \multicolumn{6}{|l|}{ BRASSICACEAE } \\
\hline $\begin{array}{l}\text { Rorippa nasturtium-aquaticum (L.) } \\
\text { Hayek (864MP) }\end{array}$ & Berro & Streams (winter) & Basal leaves & $\begin{array}{l}\text { Raw in salads, sometimes } \\
\text { stewed (TC) }\end{array}$ & 11 \\
\hline \multicolumn{6}{|l|}{ CAPRIFOLIACEAE } \\
\hline Sambucus nigra L. (874MP) & Saúco & $\begin{array}{l}\text { Around villages } \\
\text { (autumn) }\end{array}$ & Fruits & Raw; jam; syrup (C) & 7 \\
\hline Viburnum lantana L. (248MP) & Matacano & Hedges (summer) & Fruits & Raw, overripe; jam (A) & 13 \\
\hline \multicolumn{6}{|l|}{ ERICACEAE } \\
\hline $\begin{array}{l}\text { Arctostaphylos uva-ursi (L.) Spreng. } \\
\text { (342MP) }\end{array}$ & Garrolla & $\begin{array}{l}\text { Scrublands } \\
\text { (summer) }\end{array}$ & Fruits & Raw (A) & 5 \\
\hline Vaccinium myrtillus L. (753MP) & Ráspano & $\begin{array}{l}\text { Scrublands } \\
\text { (summer) }\end{array}$ & Fruits & Raw; jam (TC) & 18 \\
\hline \multicolumn{6}{|l|}{ FABACEAE } \\
\hline Trifolium alpinum L. (MA683010) & Regaliz & $\begin{array}{l}\text { Highland meadows } \\
\text { (summer) }\end{array}$ & Roots & $\begin{array}{l}\text { Sucked; also sold in } \\
\text { festivals (A) }\end{array}$ & 3 \\
\hline
\end{tabular}




\begin{tabular}{|c|c|c|c|c|c|}
\hline Family/species/voucher number & Local name & $\begin{array}{l}\text { Collecting place } \\
\quad \text { (season) }\end{array}$ & Parts used & $\begin{array}{c}\text { Popular use } \\
\text { (prevalence of use }^{\mathrm{a}} \text { ) }\end{array}$ & $\begin{array}{l}\text { Frequency of } \\
\text { citation }\end{array}$ \\
\hline \multicolumn{6}{|l|}{ FAGACEAE } \\
\hline Castanea sativa Mill. (MA657632) & Castaña & Forests, gardens & Fruits & Raw, dried (TC) & 5 \\
\hline Fagus sylvatica L. (1338 MP) & Hayuco & Forests (autumn) & Fruits & $\begin{array}{l}\text { Raw, dried; sometimes } \\
\text { toasted (A) }\end{array}$ & 6 \\
\hline \multicolumn{6}{|l|}{ GROSSULARIACEAE } \\
\hline Ribes alpinum L. (327MP) & Raspanilla & Hedges (summer) & Fruits & Raw (A) & 14 \\
\hline Ribes uva-crispa L. (706MP) & Escrébene & $\begin{array}{l}\text { Hedges, gardens } \\
\text { (summer) }\end{array}$ & Fruits & Raw (A) & 11 \\
\hline \multicolumn{6}{|l|}{ IRIDACEAE } \\
\hline $\begin{array}{l}\text { Romulea bulbocodium (L.) Sebast. \& } \\
\text { Mauri (1241MP) }\end{array}$ & Curcubilla & Pastures (spring) & Bulbs & Raw, by children (A) & 4 \\
\hline \multicolumn{6}{|l|}{ LAMIACEAE } \\
\hline Lamium maculatum L. (364MP) & Mamatetas & Edges (spring) & Flowers & Sucked $(\mathrm{A})$ & 3 \\
\hline Origanum vulgare L. (2MP) & Orégano & $\begin{array}{l}\text { Scrublands, home } \\
\text { gardens (summer) }\end{array}$ & $\begin{array}{l}\text { Flowered aerial } \\
\text { part }\end{array}$ & $\begin{array}{l}\text { Seasoning for black } \\
\text { pudding ('morcillas'), pork, } \\
\text { potatoes stews (TC) }\end{array}$ & 20 \\
\hline Sideritis hyssopifolia L. (1058MP) & Té de lastra & $\begin{array}{l}\text { Rocky places } \\
\text { (summer) }\end{array}$ & Inflorescences & $\begin{array}{l}\text { Herbal tea, in breakfast or } \\
\text { after meals (TC) }\end{array}$ & 4 \\
\hline $\begin{array}{l}\text { Thymus zygis Löfl. ex L. subsp. zygis } \\
(1435 \mathrm{MP})\end{array}$ & Tomillo & $\begin{array}{l}\text { Rocky places } \\
\text { (summer) }\end{array}$ & $\begin{array}{l}\text { Flowered aerial } \\
\text { part }\end{array}$ & $\begin{array}{l}\text { Seasoning for flesh and } \\
\text { stews }(C)\end{array}$ & 3 \\
\hline \multicolumn{6}{|l|}{ LAURACEAE } \\
\hline Laurus nobilis L. (444MP) & Laurel & $\begin{array}{l}\text { Forests, gardens } \\
\text { (all seasons) }\end{array}$ & Leaves & $\begin{array}{l}\text { With potatoes, beans, chick } \\
\text { peas, meat, fish or chicken } \\
\text { stewed; seasoning for flesh } \\
\text { or rice pudding (TC) }\end{array}$ & 10 \\
\hline \multicolumn{6}{|l|}{ LILIACEAE } \\
\hline Fritillaria pyrenaica L. (743MP) & Jarras & $\begin{array}{l}\text { Wet meadows } \\
\text { (spring) }\end{array}$ & Flowers & Sucked, by children (A) & 5 \\
\hline
\end{tabular}


Malus sylvestris Mill. (757MP)

Mespilus germanica L. (700MP)

Prunus avium L. (701MP)

Prunus cerasus L. (703MP)

Prunus insititia L. (702MP)

Prunus spinosa L. (1378MP)

Rosa canina L. s.l. (1156MP)

Rubus ulmifolius Schott. (MA620782)

Local name

Tárrago

Bragas de cuco

Meadows (spring)

Flowers

Hedges (autumn)

Edges, forests

(summer)

Maella

Níspero

Cereza

Guinda

Andriniega

Andrina

Escalambrojo

Carnero

Mora

Carnero
Hedges; forests

(autumn)

Around villages

(autumn)

Around villages,

forests (summer)

Around villages,

hedges (summer)

Hedges (autumn)

Hedges (autumn)

Hedges, pastures

(autumn)

(spring)

Hedges (autumn)

(spring)

$\begin{array}{ll}\text { Fruits } & \text { Raw (A) } \\ \text { Fruits } & \text { Raw (C?) }\end{array}$

Fruits

Fruits

Fruits

Fruits

Fruits

Fruits

Fruits

Fruits

Fruits

Fruits

Young shoots

peeled

Fruits

Young shoots peeled

Raw (TC)

Raw (A)

Raw (A)

Raw (A)
Raw; stewed (A)

Liqueur (TC)

Eaten raw, over-ripe (A)

Liqueur (TC)

Liqueur ('pacharán') (TC)

Raw, over-ripe (A)

Liqueur ('pacharán') (TC)

Raw, over-ripe (A)

Raw; for making cakes (C?)

Raw; jam (TC)

citation

35

3

17

10

16

5

3

5

4

7

16

14

5

18

11

16

14 
Table I (Continued)

\begin{tabular}{|c|c|c|c|c|c|}
\hline Family/species/voucher number & Local name & $\begin{array}{l}\text { Collecting place } \\
\text { (season) }\end{array}$ & Parts used & $\begin{array}{c}\text { Popular use } \\
\text { (prevalence of use } \mathrm{e}^{\mathrm{a}} \text { ) }\end{array}$ & $\begin{array}{l}\text { Frequency of } \\
\text { citation }\end{array}$ \\
\hline Sorbus aria (L.) Crantz (815MP) & Mostaja & Forests (autumn) & Fruits & Raw, overripe (A) & 14 \\
\hline Sorbus domestica L. (908MP) & Jerba & $\begin{array}{l}\text { Hedges, orchards } \\
\text { (autumn) }\end{array}$ & Fruits & Raw, overripe (A) & 6 \\
\hline \multicolumn{6}{|l|}{ SCROPHULARIACEAE } \\
\hline Pedicularis schizocalyx L. (751MP) & Chupetes & Meadows (spring) & Flowers & Sucked (A) & 11 \\
\hline \multicolumn{6}{|l|}{ URTICACEAE } \\
\hline Urtica dioica L. (1341MP) & Ortiga & $\begin{array}{l}\text { Around villages } \\
\text { (all seasons) }\end{array}$ & Leaves and stems & $\begin{array}{l}\text { Stewed, in stews or } \\
\text { omelettes (A) }\end{array}$ & 3 \\
\hline
\end{tabular}

aprevalence of use: A, abandoned; C, consumed; TC, traditionally consumed. 
Some fruits (e.g. Prunus spinosa) were consumed after the first frosts when they became over-ripe. To help ripen fruits such as Viburnum lantana or Mespilus germanica, these were placed in bundles of hay or wheat. Other fruits such as Vaccinium myrtillus, Rubus ulmifolius or Corylus avellana were eaten either directly or at home without preparation. Rubus ulmifolius berries were crushed and sugar added to them, and Fagus sylvatica seeds roasted in the bread oven. Dried fruits (e.g. Fagus sylvatica), and other fruits (e.g. Prunus spinosa, Malus sylvestris) were stored in an adequate place and eaten some weeks or months after gathering.

A significant number of plants were used to elaborate spirits. Prunus spinosa or Prunus cerasus were generally used. Some people also prepared herb liqueurs with Sideritis hyssopifolia or Scandix australis. Nowadays it is very popular to prepare a liqueur known as 'pacharán'. This is usually made with anisette and liquor (in proportions depending on personal preference), Prunus spinosa fruits, cinnamon bark, a few coffee seeds and sugar. Some people like to substitute the above berries by for those of Prunus insititia, or to add the inflorescences of Chamaemelum nobile, the fruits of Malus sylvestris, green walnuts or raw chickpeas. These have to macerate for 3-4 months but some people prefer to leave the mixture for up to 1 year. To obtain a better appearance, the liqueur is strained, although sometimes fruits are left in the final beverage.

Condiments and plants used to prepare herbal teas are dried in a cool place. Nearly every family once made use of Origanum vulgare, at least for preparing the products of the pig slaughter. Another wild condiment used was Laurus nobilis, which does not live wild in the region although it is frequently cultivated; many people still gather it in nearby villages.

\section{Discussion}

Botanical analysis: Plants used and food use categories

According to their frequency of citation, the most important species were R. acetosa and Rorippa nasturtium-aquaticum among the green vegetables, Origanum vulgare among the condiments, and Rosa canina, Vaccinium myrtillus, Crataegus monogyna, Prunus spinosa, Malus sylvestris, Sorbus aria, Rubus ulmifolius, Ribes alpinum, Viburnam lantana, Conglus avellana and Ribes uva-crispa among the fruits. Only three of the 14 most cited species were not used for their fruits.

Spirits made from herbs were less commonly produced in the Campoo than in other areas of Cantabria, such as Liébana, although many people prepared liqueurs by macerating fruits. Infusions were mostly prepared with Sideritis hyssopifolia inflorescences.

Ethnobotanical comparisons with nearby regions are not easily made since the surveys undertaken have had different aims and the techniques they employed were commonly quite different. However, a survey using similar methods carried out in Piloña (Asturias; San Miguel 2004) provides good material for such a comparison. The species Rumex acetosa, Sideritis hyssopifolia, Vaccinium myrtillus, Crataegus monogyna, Prunus spinosa, Rubus ulmifolius and Fragaria vesca were mentioned very often in both studies. The frequency of mention of fruits was also higher than that of vegetables.

The most cited species have been frequently consumed in nearby areas of Cantabria (Pardo-de-Santayana et al. personal observations; Lastra 2003) and other Spanish provinces. Some of the species gathered and consumed in the Campoo are less well documented in other Iberian ethnobotanical papers. 
The present work is the first to record the sucking of Pedicularis schizocalyx flowers, frequently consumed for their sweet nectar. Pedicularis sylvatica L. may have had the same use in Galicia (where it is known as chuchameles; honey suckers) (Losada et al. 1992). Other flowers such as Lamium maculatum and Fritillaria pyrenaica were also sucked. The former was also used in Piloña (San Miguel 2004), and related species of both taxa such as Lamium purpureum L. (Pieroni 1999) and Fritillaria lusitanica L. (Verde et al. 1998) have been consumed in other regions. These kinds of use are linked to children's habits and may be under-documented.

No reference of consuming the immature fruits of Convolvulus arvensis and Tilia platyphyllos was recorded, with both only mentioned by one informant respectivelyalthough it is known that Tilia fruits were milled and used as a substitute for chocolate (Rivera and Obón 1991).

Although Tamus communis L., Bryonia dioica Jacq. and other species that are consumed as asparagus in many Spanish regions (e.g. Ferrández and Sanz 1993; Blanco 1998; Verde et al. 2000) are quite common in the Campoo, none of them were gathered in the study area. In fact, both species were called 'uvas de perro' (dog's grapes), a pejorative name alluding to the toxicity of their fruits.

Scolymus hispanicus and Foeniculum vulgare Mill. are further examples of plants commonly consumed in other regions but not in the Campoo. In the study area, according to one informant, only gypsies gathered the young leaves of Foeniculum vulgare for use as green vegetables, cooking them with cabbage. It is interesting to note that the cooking of the young leaves of this species is considered, in both the Campoo and in the Provinces of Segovia (Blanco 1998) and Madrid (authors personal observations), as a sign of belonging to a marginal community. This species is commonly consumed raw in Spain (Mulet 1991; Martínez Lirola et al. 1997) or as a seasoning plant for olives (Galán 1993; Verde et al. 1998), but to eat it cooked is common only in certain areas (e.g. Murcia and Andalusia; Mesa 1996; Martínez Lirola et al. 1997; Verde et al. 1998). Although eating cooked Foeniculum vulgare usually has no ethnical connotation in the latter areas, certain dishes such as 'olla gitana' (Rabal 2000) or 'potaje de habichuelas' (Casana 1993) are considered gypsy food.

It is interesting that some people enjoyed eating Sambucus nigra fruits, while many others considered them inedible. Some informants reported that their parents forbade them to eat these tasty fruits. The reasoning behind these contradictory ideas could lie in the legend, remembered by some people in Cantabria (V. Fernández, personal communication), that associates the elder with the tree in which Judas hanged himself (Folkard 1884; Cleene and Lejeune 2003).

Table II compares the wild foods consumed in some Mediterranean territories. Due to the heterogeneity of criteria used by the authors of the cited papers, plants consumed as condiments, liqueurs or infusions were excluded. The high percentage of species consumed for their fruits or seeds in the Campoo $(56 \%)$ and Pilona $(60 \%)$ are remarkable compared with Garfagnana (18\%), Montseny (28\%), Madrid (34\%) and Central Anatolia (39\%). It is also interesting that the percentage of fruits and seeds $(56 \%)$ is higher than that for leaves and stems (29\%) (mainly used as green vegetables).

Cultivated fruit trees are of low productivity in the Campoo since severe storms, hailstorms and freezing temperatures are common during spring. The lack of money and limited fruit supply in the markets, especially in winter, meant people could not buy commercial fruits; rather, they had to depend on countryside fruits such as Mespilus germanica, Sorbus domestica, Malus sylvestris or Prunus spinosa. Although 
Table II. Wild edible species, excluding plants used for seasoning, making liqueurs or infusions, compiled in some Mediterranean ethnobotanical studies.

\begin{tabular}{lccccc}
\hline Study area & $\begin{array}{c}\text { Number of } \\
\text { species }\end{array}$ & $\begin{array}{c}\text { Leaves and } \\
\text { stems }\end{array}$ & $\begin{array}{c}\text { Fruits and } \\
\text { seeds }\end{array}$ & $\begin{array}{c}\text { Subterranean } \\
\text { part }\end{array}$ & Flowers \\
\hline $\begin{array}{l}\text { Piloña, Asturias, Spain } \\
\quad \text { San Miguel 2004) }\end{array}$ & 25 & $7(28 \%)$ & $15(60 \%)$ & $2(8 \%)$ & $2(8 \%)$ \\
$\begin{array}{l}\text { Madrid, Spain (Tardío et al. 2002) } \\
\text { Montseny, Catalonia, Spain } \\
\quad(\text { Bonet and Vallès 2002) }\end{array}$ & 87 & $49(56 \%)$ & $30(34 \%)$ & $2(2 \%)$ & $8(9 \%)$ \\
$\begin{array}{l}\text { Campoo, Cantabria, Spain } \\
\quad(\text { Pardo de Santayana 2004) }\end{array}$ & 48 & $28(61 \%)$ & $13(28 \%)$ & $2(4 \%)$ & $4(9 \%)$ \\
$\begin{array}{l}\text { Garfagnana, Italy (Pieroni 1999) } \\
\text { Central Anatolia, Turkey }\end{array}$ & 90 & $70(78 \%)$ & $16(18 \%)$ & $6(7 \%)$ & $1(1 \%)$ \\
$\quad($ Ertug 2000) & 88 & $44(50 \%)$ & $34(39 \%)$ & $7(8 \%)$ & $3(3 \%)$ \\
\hline
\end{tabular}

these plants are not very productive, they are well adapted to the local climatic conditions.

\section{Current and past uses}

Although we have only a few pieces of archaeobotanical evidence from the surrounding areas of Cantabria (L. Peña-Chocarro, personal communication) and the Basque Country (Peña-Chocarro and Zapata 1996; Zapata 2000, 2002), the role of these plants in subsistence during prehistoric times and at the beginning of agriculture was undoubtedly very important.

The above evidence shows that the early settlers of northern Spain used to eat many fruits such as Arbutus unedo L., Corylus avellana, Fagus sylvatica, Prunus spinosa, Rubus sp., Quercus sp., Sorbus sp. and vegetables such as Urtica dioica or Rumex sp. (Zapata 2002). According to the Greek geographer Strabo (first century BC-first century AC), the 'Cántabros' (Iberian tribes that lived in the area before the Roman conquest) used to eat bread made from acorn flour (see García Bellido 1945).

In the present study, some informants noted that during the Spanish Civil War (1936-1939) and the post-war period, the local people did not suffer such great hunger as in other rural areas where gathering wild vegetables became more common (González Turmo 1997; Tardío et al. 2005). Although the Campoo's soils are not very fertile, the agriculture-livestock tandem allowed people to subsist, and times of scarcity were not so hard.

The survey showed that more than one-half of the uses reported are no longer current (see Table I, prevalence of use). Most of the wild fruits, bulbs and other greens mentioned were consumed by children as an amusement or to avoid feeling hungry on the way to school, at break time, or when they were far from home taking care of livestock or helping during threshing time.

This steady erosion of traditional knowledge contrasts with the growing use of selfcultivated food plants, which are now those mostly used (Pardo-de-Santayana 2004). As San Miguel (2004) also indicated for Asturias, food is a very conservative aspect of culture. The fact that many wild foods are no longer collected appears to be due to the negative connotations attached to them; that is, their being linked to times of scarcity or hard manual labour that most people prefer not to remember. A few people may still consume wild greens. It is now more common for people to make jams, desserts or 
spirits with wild berries. The use of species such as Valerianella carinata is new to the area; one of the two informants who used to gather it told us that foreigners had shown her how to make use of this plant.

Only a few species have been marketed. However, the demand for handicrafts and local gastronomic products such as jams and spirits has grown with the increase in rural tourism, which requires quality local food be available. There is a shop in Reinosa, the most important town of the region, which sells jams and other homemade products that are now distributed as typical products in other tourist regions of Cantabria. Sambucus. nigra, Rubus ulmifolius and Vaccinium myrtillus jams can be bought that have been prepared in the traditional way, with recipes learned from books or on courses organized by local development agencies.

The new appreciation of 'natural products' has helped develop new ways of making spirits. It is popular to prepare and consume them at home, but they can be also enjoyed in restaurants, and so on, as quality local products. People like to try new flavours and they are now preparing spirits with plants that were never used in the past (e.g. acorns or the fruits of Rosa canina or Sambucus nigra).

In recent decades, the fruits of $P$. spinosa have been gathered in nearly all territories were they are produced in order to prepare a liqueur known as 'pacharán'. This is made both at home and by industrial concerns, and people from the area have gathered these berries to sell them.

The tradition of collecting mushrooms, another kind of wild food, is also alive in the Campoo, although it is not as important as in other regions, such as the Basque Country (Barandiarán and Manterola 1990). Only a few species were traditionally gathered and are still appreciated. Most of them are collected in spring. In fact, the most popular, Calocybe gambosa (Fr.) Donk is locally known as the 'seta de primavera' (spring mushroom). Most people gather them for their own use, but they are also sold to restaurants in the region or in nearby cities (e.g. Santander or Bilbao). At the beginning of the season, Calocybe gambosa can reach very high prices (€240/kg), falling thereafter to $€ 6-12 / \mathrm{kg}$.

\section{Food medicines}

Only a few wild vegetables or fruits were deliberately eaten for health purposes. Rorippa nasturtium-aquaticum was considered an excellent 'purifier of the blood' and Sorbus domestica fruits were consumed for their astringent qualities in the treatment of diarrhoea.

Infusions and spirits were formerly prepared as digestifs, but they are now consumed for their medicinal properties, for their flavour and as a social beverage. Such is the case of Sideritis hyssopifolia, the infusion or liqueur of which is considered a gastronomic attraction for tourists in the nearby Picos de Europa mountains (Pardo-de-Santayana et al. 2005). Similar conclusions were made in an ethnographic survey of traditional foods of the Basque Country (Barandiarán and Manterola 1990).

When all the species used are taken into account, both medicinal and edible, the percentage of cultivated taxa $(55 \%)$ is higher than that of wild species (45\%) (Pardode-Santayana 2004). This is reasonable, especially in a settled rural society, given the greater cultural significance of cultivated plants, around which many habits, traditions, ideas and uses have been built. However, the percentage of medicinal plants gathered in the wild was higher than those cultivated species ( $61 \%$ compared 
with $39 \%$ ). In fact, many plants were formerly regarded only as medicines, and many people believe that such plants have more powerful healing properties when collected from the wild. Barandiarán and Manterola (1990) reported that in the Basque Country some wild vegetables such as Urtica dioica and many beverages (infusions and spirits) were formerly regarded only as medicinal, and not as food.

\section{Plant supply, management and conservation}

There is a complex gradient between plants that grow wild and those that are cultivated. All the plants considered wild in this paper grow in managed ecosystems such as forests, meadows or hedgerows; the term includes 'promoted', managed, transplanted and tolerated species. Only a few could be awarded the strict status of 'managed plants'; that is, those that grow naturally but are helped along by humans (e.g. by weeding). This is the case of Prunus insititia, Sambucus nigra and Malus sylvestris, which grow in home gardens or in the surroundings of villages, and thorny bushes such as Prunus spinosa, Crataegus monogyna, Rubus ulmifolius, Rosa canina or Ribes uva-crispa, which typically grow in hedgerows.

Other species such as Corylus avellana can be considered wild, managed or cultivated. They may grow wild, dispersed in forests, but plant communities dominated by $C$. avellana can be found around some villages specialized in basketry or broomstick-making. These communities exist due to the exploitation of the wood; appropriate branches are harvested and all weeds and unwanted species removed. They can be also found in hedges where they have been transplanted. Other plants transplanted into gardens are Laurus nobilis, Origanum vulgare and Ribes uva-crispa.

Another category of species includes species such as Crataegus monogyna, Prunus spinosa or Malus sylvestris which are used for grafting fruit trees such as Mespilus germanica, Pyrus communis, Prunus communis, Sorbus domestica or Malus domestica. It is difficult to decide whether some samples of allochthonous species such as Mespilus germanica and Sorbus domestica (which are naturalized in the area) should be considered within this category since it is sometimes impossible to know if they have been grafted.

The majority of the edible plants mentioned were species commonly found in the surroundings of villages, in hedgerows or in meadows. Similar conclusions have been made in other ethnobotanical surveys (Agelet et al. 2000; Bonet and Vallès 2002). However, in the Campoo, the percentage of weeds and other plants that live in these habitats is very low (15\%) compared with that of other Mediterranean areas (see, for example, Pieroni et al. 2002).

The species collected are not endangered. Most are abundant with a vast area of distribution. The only species whose availability was reported reduced due to overexploitation and bad gathering practices was Rorippa nasturtium-aquaticum. This plant requires clean, clear streams in which to grow-environments that are now endangered.

\section{Acknowledgements}

The authors are grateful to all the people of the Campoo who kindly shared their knowledge and time and helped them to meet other people in the area. They thank M. Alexiades and A. Burton for revising and improving the manuscript. They also thank the Spanish Ministry of Education for the grant that financed this work. 


\section{References}

Agelet A, Bonet MA, Vallès J. 2000. Homegardens and their role as main source of medicinal plants in Mountain regions of Catalonia (Iberian Peninsula). Econ Bot 54:295-309.

Alexiades MN. 1996. Collecting ethnobotanical data: an introduction to basic concepts and techniques. In: Alexiades $\mathrm{MN}$, editor. Selected guidelines for ethnobotanical research. Bronx, NY: The New York Botanical Garden. pp 53-94.

Barandiarán JM, Manterola A. 1990. La alimentación doméstica en Vasconia. Bilbao: Eusko Jaurlaritza; Etniker Euskalerria.

Blanco E. 1996. El Caurel. Las plantas y sus habitantes. Estudio etnobotánico de la Sierra del Caurel (Lugo). La importancia de las plantas para nuestros antepasados. Santiago de Compostela: Fundación Caixa Galicia.

Blanco E. 1998. Diccionario de etnobotánica segoviana. Pervivencia del conocimiento sobre las plantas. Segovia: Ayuntamiento de Segovia, Caja Segovia, Diputación de Segovia, Junta de Castilla y León.

Bonet MA, Vallès J. 2002. Use of non-crop food vascular plants in Montseny biosphere reserve (Catalonia, Iberian Peninsula). Int J Food Sci Nutr 53:225-248.

Casana E. 1993. Patrimonio etnobotánico de la provincia de Córdoba: Subbética, campiña y vega del Guadalquivir [dissertation]. Córdoba: University of Córdoba.

Cleene M, Lejeune MC. 2003. Compendium of symbolic and ritual plants in Europe. Ghent: Man \& Culture Publishers.

Ertug F. 2000. An ethnobotanical study in Central Anatolia (Turkey). Econ Bot 54:155-182.

Ertug F. 2004. Wild edible plants of the Bodrum Area (Mugla, Turkey). Turk J Bot 28:161-174.

Ferrández JV, Sanz JM. 1993. Las plantas en la medicina popular de la Comarca de Monzón (Huesca). Huesca: Instituto de Estudios Altoaragoneses, Diputación de Huesca.

Folkard R. 1884. Plant lore, legends and lyrics. London: Sampson Low.

Galán R. 1993: Patrimonio etnobotánico de la provincia de Córdoba: Pedroches, Sierra Norte y vega del Guadalquivir [dissertation]. Córdoba: University of Córdoba.

García Bellido A. 1945. España y los españoles hace dos mil años, según la 'Geografía' de Strabón. Madrid: Espasa Calpe.

González Turmo I. 1997. Comida de rico, comida de pobre. Los hábitos alimenticios en el Occidente andaluz (Siglo XX). Sevilla: Universidad de Sevilla.

Guarrera PM. 2003. Food medicine and minor nourishment in the folk traditions of Central Italy (Marche, Abruzzo and Latium). Fitoterapia 74:515-544.

Johns T, Kokwaro JO, Kimanani EK. 1990. Herbal remedies of the Luo of Sykia District, Kenya: establishing quantitative criteria for consensus. Econ Bot 44:369-381.

Lastra JJ. 2003. Etnobotánica en el Parque Nacional de Picos de Europa. Oviedo: Ministerio de Medio Ambiente, Parques Nacionales.

Losada E, Castro J, Niño E. 1992. Nomenclatura vernácula da flora vascular galega. La Coruña: Xunta de Galicia.

Martínez Lirola MJ, González-Tejero MR, Molero J. 1997. Investigaciones Etnobotánicas en el Parque Natural de Cabo de Gata-Níjar (Almería). Almería: Sociedad Almeriense de Historia Natural.

Mesa S. 1996. Estudio Etnobotánico y Agroecológico de la comarca de la Sierra Mágina [dissertation]. Madrid: Complutense University of Madrid.

Mulet L. 1991. Estudio etnobotánico de la provincia de Castellón. Castellón: Diputación de Castellón.

Pardo-de-Santayana M. 2004. Las plantas en la cultura tradicional de la Antigua Merindad de Campoo [PhD dissertation Published in CDRom]. Madrid: Autónoma University of Madrid.

Pardo-de-Santayana M, Gómez Pellón E. 2003. Etnobotánica: aprovechamiento tradicional de plantas y patrimonio cultural. An Jard Bot Madrid 60:171-182.

Pardo-de-Santayana M, Blanco E, Morales R. 2005. Plants known as "té" (tea) in Spain. An ethnopharmaco-botanical review. J Ethnopharmacol 98:1-19.

Peña-Chocarro L, Zapata L. 1996. Los recursos vegetales en el mundo romano: estudio de los macrorrestos botánicos del yacimiento calle Santiago de Irún (Guipúzcoa). Arch Esp Arqueol 69:119-134.

PFAF, 2005. Plants for a future: edible, medicinal and useful plants for a healthier World. Resource and Information Centre for Edible and other useful plants. Database. Available at: http://www.ibiblio.org/pfaf/ D_search.html.

Pieroni A. 1999. Gathered wild food plants in the Upper Valley of the Serchio River (Garfagnana), Central Italy. Econ Bot 53:327-341. 


\section{M. Pardo-de-Santayana et al.}

Pieroni A. 2000. Medicinal plants and food medicines in the folk traditions of the upper Lucca Province, Italy. J Ethnopharmacol 70:235-273.

Pieroni A, Nebel S, Quave C, Münz H, Heinrich M. 2002. Ethnopharmacology of liakra: traditional weedy vegetables of the Arbëreshë of the Vulture area in southern Italy. J Ethnopharmacol 81:165-185.

Pieroni A, Nebel S, Santoro RF, Heinrich M. 2005. Food for two seasons: Culinary uses of non-cultivated local vegetables and mushrooms in a south Italian village. Int J Food Sci Nutr 56:245-272.

Rabal G. 2000. 'Cuando la chicoria echa flor ...' Etnobotánica en Torre Pacheco. Rev Murciana Antropol $6: 1-240$.

Rivera D, Obón C. 1991. La guía de Incafo de las plantas útiles y venenosas de la Península Ibérica y Baleares (excluidas medicinales). Madrid: Incafo.

San Miguel E. 2004. Etnobotánica de Piloña (Asturias). Cultura y saber popular sobre las plantas en un concejo del Centro-Oriente Asturiano [dissertation]. Madrid: Autónoma University of Madrid.

Scarpa GF. 2000. Estudio etnobotánico de la subsistencia de los 'criollos' del Chaco Noroccidental argentino [dissertation]. Buenos Aires: University of Buenos Aires.

Tardío J, Pascual H, Morales R. 2002. Alimentos silvestres de Madrid. Guía de plantas y setas de uso alimentario tradicional en la Comunidad de Madrid. Madrid: Real Jardín Botánico, CSIC, La Librería, Instituto Madrileño de Investigación Agraria y Alimentaria.

Tardío J, Pascual H, Morales R. 2005. Wild food plants traditionally used in the province of Madrid. Econ Bot 59:122-136.

Verde A, Rivera D, Fajardo J, Obón C. 2000. Etnobotánica del entorno del Parque Nacional de Cabañeros, Parques Nacionales.

Verde A, Rivera D, Obón C. 1998. Etnobotánica en las Sierras de Segura y Alcaraz: las plantas y el hombre. Albacete: Instituto de Estudios Albacentes de la Excma, Diputación de Albacete.

Zapata L. 2000. La recolección de plantas silvestres en la subsistencia mesolítica y neolítica. Datos arqueobotánicos del País Vasco. Complutum 11:157-169.

Zapata L. 2002. Origen de la agricultura en el País Vasco y transformaciones en el paisaje: análisis de restos vegetales arqueológicos. Kobie 4. Bilbao: Diputación Foral de Vizcaya. 